\title{
The Right to Residency: Mobility, Tuition, and Public Higher Education Access
}

\author{
Camille Walsh* \\ School of Interdisciplinary Arts \& Sciences, University of Washington Bothell, USA \\ *Corresponding author. Email: camwalsh@uw.edu
}

\begin{abstract}
This article argues that the now-widespread US practice of residency-based tuition differentials for public higher education institutions is a twentieth-century form of higher education exceptionalism carved out in law and state policy, contradicting otherwise cherished and protected rights of free movement. This contradiction has been enabled in part by the vague standard of constitutional protection for the right to interstate mobility and in part by fiscal deference to public universities that quickly recognized the potential benefits of higher nonresident tuition rates. By both defining higher education as outside of the "necessities of life" and upholding a narrative that the children of state residents had a special entitlement to lower tuition as a kind of "legacy" taxpayer inheritance, courts, legislatures, and educational institutions built a modern higher education finance structure that discriminates against the mobility of "newcomers" and any student with a complicated family structure or residency status.
\end{abstract}

Keywords: residency; higher education; access; public education; inequality; tuition

In 1968, Wanda Lindsay wrote a letter to Max Rafferty, the California State Superintendent of Public Instruction, angry that a young man whose father worked for the US government and was stationed overseas was awarded a scholarship. Questioning the legitimacy of the young man's award and claim to California residency (he lived with his grandmother in California), she told Rafferty that her letter was indeed based on "bitterness and anger" because she was "a member of a family which has paid taxes in California since 1850." She concluded that the "tax paying members" of her family were "tired of the discrimination being practiced against those of us who have been law-abiding, productive, constructive, citizens, whose only $\sin$ is that we are Americans and not hyphenated Americans." ${ }^{1}$ Similarly, California resident and parent Mary Ball wrote a letter to Governor Ronald Reagan in 1974 arguing that "long-time state residency" should be a requirement for admission to California universities. Since her husband was a native Californian whose

\footnotetext{
${ }^{1}$ Lindsay was the mother of a student denied a scholarship (her family apparently made too much money). Wanda Lindsay to Max Rafferty, June 20, 1968, folder 7, routine files, box 30, series 6, CU-5, Office of the President Records, Bancroft Library, University of California, Berkeley.

(C) History of Education Society 2021. This is an Open Access article, distributed under the terms of the Creative Commons Attribution licence (http://creativecommons.org/licenses/by/4.0/), which permits unrestricted re-use, distribution, and reproduction in any medium, provided the original work is properly cited.
} 
family had lived there since 1910 she asked, "shouldn't California give preference to Californians, particularly by seniority, since so many Californians originated elsewhere?"2 These nativist claims to entitlements based on strict definitions of state residency and an idea of a sort of taxpayer inheritance model were not new, but became particularly heightened in the postwar rapid expansion of public higher education systems.

By the 1960s and 1970s, as public universities and colleges had exploded in growth, state borders in the United States were also being crossed with breathtaking ease. Employment opportunities in small and large urban centers during and after WWII enabled more people than ever before to create a new life for themselves in a new state. The ability to start over in a new city and leave behind everything from regional environmental or economic difficulties to certain types of state-sponsored segregation defined many major demographic shifts in this era. ${ }^{3}$

Yet the US Constitution contains no provision explicitly recognizing the right of citizens to move from state to state without incurring legal difficulties, and states have long attempted to entrench various hurdles for newcomers and premiums for longtime residents. Public colleges and universities' uniquely specific linkages to state identity and state funding have facilitated a defense of residency benefits for education even as residency arguments in other areas have declined. This article will analyze the role that residency laws and requirements played in access to public higher education during the postwar decades of higher education's most rapid increase. I argue that public higher education's lauded expansion in the twentieth century was also intertwined with a reliance on state residency tuition differentials rooted in an assumption of state resident priority and deservingness. From the letters above to the US Supreme Court, educational benefits as an exclusive reward for state residence have been defended out of deference to state control of education and quasi-reciprocal claims of past fiscal contributions even as actual state funding has declined. The judicial protection of this legacy "taxpayer reciprocity" residency benefit has exacerbated ongoing inequalities in access to higher education institutions even as residency requirements for other benefits have loosened and expanded.

Public institutions today enroll the vast majority of US higher education students. ${ }^{4}$ But prior to 1950 , more than half of all college and university students in the US attended private institutions. ${ }^{5}$ As the numbers of those attending public

\footnotetext{
${ }^{2}$ Mary Ball to Ronald Reagan, June 13, 1974, folder 14, President's Records.

${ }^{3}$ For a far-ranging discussion of the many internal demographic shifts and the complex circumstances that inspired migration in the twentieth century, see Isabel Wilkerson, The Warmth of Other Suns: The Epic Story of America's Great Migration (New York: Vintage, 2011); James R. Grossman, Land of Hope: Chicago, Black Southerners, and the Great Migration (Chicago: University of Chicago Press, 1991); James N. Gregory, The Southern Diaspora: How the Great Migrations of Black and White Southerners Transformed America (Chapel Hill: University of North Carolina Press, 2005); and James N. Gregory, American Exodus: The Dust Bowl Migration and Okie Culture in California (Oxford, UK: Oxford University Press, 1991).

${ }^{4}$ Steven W. Hemelt and Dave E. Marcotte, "The Changing Landscape of Tuition and Enrollment in American Public Higher Education," RSF: The Russell Sage Foundation Journal of the Social Sciences 2, no. 1 (April 2016), 42-68.

${ }^{5}$ Western State Interstate Commission for Higher Education, "Higher Education and the State: The Public's Current Concerns," Dec. 4, 1967, folder 23, box 79, President's Records.
} 
institutions have grown, so has the presumption of low tuition-once upon a time, no tuition-as an exclusive benefit accorded to state residents. ${ }^{6}$ Indeed, the accepted narrative of public higher education today simply assumes the existence of a substantial out-of-state premium on tuition and a high bar for residency for lower tuition purposes. This assumption relies on a public higher education system predominantly state-supported through taxes on state residents. Therefore, the logic goes, parents who live in the state and have paid state taxes to support this state system should be able to obtain a lower-cost higher education opportunity for their adult children. $^{7}$

This article argues that courts, state governments, and institutions themselves have helped create and solidify a "higher education exceptionalism" around the otherwise crucial right to residency, interstate migration, and mobility. This form of exceptionalism removes higher education benefits (and indeed, education benefits in general) from the otherwise rigorous constitutional demands of national citizenship and the protected right to mobility placed on other kinds of state benefits, from voting to welfare to medical care. Even the right to divorce, once treated comparably to education as a "portable" benefit, has now been broadened in almost every state to welcome new residents quickly. Ultimately, this exceptionalism around educational access has become entrenched through a series of vague decisions around the right of interstate movement and the portability of education as well as a deep deference to public higher educational decision-making authority as unique from other institutions.

Historians have tended to pay less attention to the topic of residency requirements and their rationales, even in otherwise extensive histories of higher education. ${ }^{8}$ The uniqueness of durational residency restrictions-applied only to public institutions, sometimes in inconsistent ways, and largely irrelevant (with some exceptions, discussed later) for most K-12 education systems-may have contributed to this. These requirements also pose a conundrum for higher education public finance conversations. If you separate state resident privileges and state resident identification from the state university, it can seem even harder to justify increasing or maintaining the level of state funding, which has been increasingly abandoned in recent decades. ${ }^{9}$

\footnotetext{
${ }^{6}$ For example, the first evidence I was able to locate of a nonresident fee existing in state law for California higher education was in 1920, which perhaps makes sense for a western state accustomed up to then to encouraging in-migration rather than protecting exclusive benefits for established residents.

${ }^{7}$ For more extensive discussion of how "taxpayer" identity claims on educational resources have harmed students of color and served to entrench unequal systems of public educational funding at the K-12 level, see Camille Walsh, Racial Taxation: Schools, Segregation, and Taxpayer Citizenship, 1869-1973 (Chapel Hill: University of North Carolina Press, 2018).

${ }^{8}$ For examples of important and sweeping histories of higher education (which naturally have to cover a huge range of subtopics) in which residency does not appear as a significant element, see Harold S. Wechsler, Lester F. Goodchild, and Linda Eisenmann, The History of Higher Education (New York: Pearson, 2007); Arthur M. Cohen and Carrie B. Kisker, The Shaping of American Higher Education (Hoboken, NJ: Wiley, 2009); John Thelin, A History of American Higher Education (Baltimore: Johns Hopkins University Press, 2019); Roger Geiger, The History of American Higher Education (Princeton, NJ: Princeton University Press, 2016); Roger Geiger, American Higher Education Since World War II (Princeton, NJ: Princeton University Press, 2019); and Charles Dorn, For the Common Good: A New History of Higher Education in America (Ithaca, NY: Cornell University Press, 2017).

${ }^{9}$ Christopher Newfield, Unmaking the Public University: The Forty-Year Assault on the Middle Class, (Cambridge, MA: Harvard University Press, 2011). Newfield argues that the abandonment of state funding
} 
Law and education scholars have discussed residency laws much more at various moments, with some of the most sustained literature on residency and higher education emerging in the early 1970s. A great deal of interest in the subject emerged in relation to expanding litigation in that decade after the Twenty-sixth Amendment changed the age of majority in 1971, but other law and education scholars have discussed the issue over the years. Scott Gelber has argued broadly that the twentieth century's growth in higher education's prestige and enrollments also saw judges and courts more likely to defer to academic institutions in tuition litigation and other types of cases, as will be seen in many residency cases. ${ }^{10}$

Legal scholar Michael A. Olivas, who surveyed the literature of postsecondary educational residency requirements in 1988, noted that the relevant literature up until then was primarily focused either on the legal or economic consequences of student migration or was more practitioner-focused, in either case offering a sort of "muddling through" explanation of how the requirements were applied. ${ }^{11} \mathrm{He}$ also pointed out that the premise of these residency systems was "nonsense in many instances" because "unless a student or a student's parents have been in longtime residence, it is unlikely that their tax contributions will equal the instructional expenditures, either at in-state or out-of-state rates." 12 After Olivas's summary, many more legal scholars have engaged with the question of legal domicile as well as tuition differentials based on residency. This scholarship often directly questions the constitutionality of these systems while acknowledging that both judicial and fiscal considerations make them unlikely to change, particularly pointing out that higher education funding has in recent decades relied on this arguably unconstitutional structure. ${ }^{13}$

Education scholar Robert F. Carbone addressed higher education residency issues extensively, publishing multiple reports and articles throughout the 1970s on the question and encouraging state higher education institutions and legislatures to adopt a National Tuition Bank program. As Carbone pointed out in his 1974 book, Alternative Tuition Systems, "Sensitive criteria, for flexible determination of payment status, more closely approximate the real transfer of resources over the actual

of public higher education has frequently been driven by forces seeking to diminish the democratizing effect of public higher education on society rather than by simple fiscal need or economic downturns.

${ }^{10}$ Scott M. Gelber, Courtrooms and Classrooms: A Legal History of College Access 1860-1960 (Baltimore: Johns Hopkins University Press, 2015).

${ }^{11}$ Michael A. Olivas, "Administering Intentions: Law, Theory, and Practice of Postsecondary Residency Requirements," Journal of Higher Education 59, no. 3 (May-June 1988), 263-90.

${ }^{12}$ Olivas, "Administering Intentions," 283-84.

${ }^{13}$ For examples of law review articles arguing against the constitutionality of residency differentials, see Hannah McCann, "Privileged for Being Stationary: Why the Practice of Differentiating Between In-State and Out-of-State Tuition Rates Are [sic] Unconstitutional," Belmont Law Review 4, Article 12 (2017), https://repository.belmont.edu/lawreview/vol4/iss1/12; John W. Anderson, "Strangers in Their Own Land: Durational Residency Requirements for Tuition Purposes, Though Illegal, Are Here to Stay," Nebraska Law Review 85, no. 4 (2007), 1058-92. Anderson argues directly that there are "real questions about its constitutionality, but the academic community relies upon the economic benefits of the practice, at least in part, to maintain fiscal integrity. Self-interest is a powerful restraint," 1059; and Michael Llewellyn, "Citizens Without Statehood: Denying Domicile to Fund Public Higher Education," West Virginia Law Review 108, no. 3 (2006), https://researchrepository.wvu.edu/wvlr/vol108/iss3/11. 
long time span."14 He argued that states "resist permitting a nonresident to establish residency for tuition purposes" because the state would have to replace the extra fee revenue, and that a federal system was necessary to bring these structures of state resistance "out of apparent conflict" with other residency-based rights and privileges (such as voting). ${ }^{15}$ A 1970 report by Carbone on resident student classification argued that "residency rules in many states appear to deny equal privileges and protection to all citizens," and he recommended a system of interstate "matchmakers" to help students attend school in nearby states. Carbone suggested that if some alternative structure was not developed, "states will continue to 'act more like foreign nations than like united states' in this regard."16

These types of "foreign nations" restrictions by states in realms such as voting and welfare were largely eliminated or greatly diminished over the course of the twentieth century, but tuition benefits have remained an outlier. Some economists have argued that these decentralized state disparities, or distortions in economic terms, can also produce inefficiencies on a national level. ${ }^{17}$ Education historian David Palley in 1976 suggested either a transfer payment plan or a waiver plan to address the "nonresident student problem" by providing national structures to deal with interstate distortions. Palley also predicted that due to leveling enrollments "many states within five to ten years will voluntarily lower public college access barriers to students from out of state." 18 Yet the opposite has happened, in part due to a range of incentives in state funding and student loan systems that have made public institutions increasingly reliant on higher tuition rates from higher proportions of nonresident students to compensate for diminished state funds. ${ }^{19}$

This article begins with a historical overview of the constitutional right to interstate travel, which is tied to everything from migration politics and demographic changes to the history of poverty and the right to vote as well as tuition differentials. Even as, by the 1970s, welfare benefits, medical care, and voting rights became interpreted as "necessities" deserving protection from state-based discrimination against new arrivals, education was increasingly carved out as a unique category. The second half of the article will examine the judicial cases around tuition residency and education as a parallel story that diverged from the other benefits cases at a key moment in the 1970s. Ultimately, courts, legislatures, and educational institutions have upheld

\footnotetext{
${ }^{14}$ Robert F. Carbone, Alternative Tuition Systems, ACT Special Report No. 12 (Iowa City, IA: American College Testing Program, 1974), 53.

${ }^{15}$ Carbone, Alternative Tuition Systems, 120.

${ }^{16}$ Robert F. Carbone, "Resident or Nonresident: The Classification of Students for Tuition Purposes in Public Colleges and Universities," received January 22, 1970, folder 8, box 30, President's Records.

${ }^{17}$ For an examination of the detrimental welfare effects on a national level of the kinds of choices hypothetical students make when navigating state residency tuition requirements, see Brian Knight and Nathan Schiff, "The Out-of-State Tuition Distortion," American Economic Journal: Economic Policy 11, no. 1 (Feb. 2019), 317-50.

${ }^{18}$ David B. Palley, "Resolving the Nonresident Student Problem: Two Federal Proposals," Journal of Higher Education 47, no. 1 (1976), 30.

${ }^{19}$ Rupert Wilkinson has written about the conflicting purposes of student aid throughout the US and the varying impulses that drove the rise of both increased tuition and increases in certain types of student aid. Rupert Wilkinson, Aiding Students, Buying Students: Financial Aid in America (Nashville, TN: Vanderbilt University Press, 2005).
} 
tuition-based benefit discrimination by pointing to both the logic of purported state (resident) fiscal contribution and by judicially defining education as a "nonnecessity."

\section{Residency and the Right to Travel between States: From the Civil War to the Civil Rights Era}

Nowhere in the Constitution is the right to interstate travel or migration stated explicitly -indeed until after the Civil War it is likely that many US citizens would have identified more with their state than their nation. But for aspiring college students in the twentieth century, moving to another state could be a declaration of freedom, a chance to start a new life, an opportunity for finding identity or community. Certainly for Black students from the segregated South, moving to another state could itself be critical to access higher education at all. ${ }^{20}$ Just as the Constitution contains no named right to interstate mobility, there is also no right to education, yet both can be understood as inextricably intertwined, particularly for educational access.

The first case to touch on the general question of voluntary interstate migration and the right of citizens to travel freely between states was immediately after the Civil War. In Crandall v. State of Nevada (1867), the Supreme Court invalidated a tax on common carrier passengers leaving the state and affirmed the importance of an individual's ability to come to the seat of government by referencing multiple constitutional provisions for invalidating the tax. ${ }^{21}$ This case is significant in reaffirming what the Civil War had shown-that the country was a sovereign nation of states, not a loose union of sovereign states.

Yet the court struggled to identify a legal rationale to support the logical outcome. After a discussion of the commerce clause-and mentioning the judiciary historically treating travel and migration of people as "imports" or "commerce"-the opinion settled on the "one common country" rationale. The court argued that the federal government's power to call officers, citizens, and troops to the seat of government unimpeded by state whims was at least as important as a citizen's right to travel to the seat of government to participate, share in governance, or petition for redress. This case highlights a hangover of sorts from the constitutional logics that protected and facilitated the slave trade through the commerce clause. The confusing legal question regarding the basis for interstate mobility rights emerged repeatedly over the following century, as courts debated whether the right to travel could correctly be located in the commerce clause or if it belonged to the individual as a person.

\footnotetext{
${ }^{20}$ By 1968, a Ford Foundation report concluded that "a substantial number of black students migrate from the South to low-cost public institutions in the Midwest." Indeed, the foundation found that nearly all reported black graduate students were in large midwestern state universities, with the East and West below the national figures, and the South higher than average (but far below the actual population of African Americans living in the region generally at the time, between 40 and 50 percent of the national population). National Association of State Universities and Land Grant Colleges, "For Your Information," Dec. 20, 1968, folder 18, box 79, President's Records.

${ }^{21}$ Crandall v. State of Nevada, 73. U.S. 35 (1867). This case also heavily referenced an 1849 set of casescombined as the Passenger Cases, 48 U.S. 7 (1849) —in which New York and Massachusetts had levied taxes on "alien passengers" arriving in their ports. Those cases, along with Crandall, laid a foundation for interpreting the right to travel as an element of commerce-an idea that the Passenger Cases acknowledged was drawn from the "importation of persons" in the slave trade prior to 1808.
} 
Decades after the Crandall case, the dramatic demographic shifts of the early twentieth century, brought on by changing regional social, political, economic, and educational opportunities and challenges, also brought various interstate tensions and exclusions. International migration shifts also brought new populations in greater numbers to the US in these decades, changing the demographic character of cities in the Northeast as well as states on the West Coast and elsewhere and leading to new forms of legal exclusion and discrimination. ${ }^{22}$ Additionally, internal migration during the Great Migration and the Dust Bowl led to increasing forms of state-based identity discrimination, as seen in a pivotal 1941 Supreme Court case on residency.

It wasn't until the Great Depression that another federal case calling into question the rights of US citizens to move freely between states emerged. After the Dust Bowl ravaged the agricultural economies of many southwestern states in the late 1920s and early 1930s, California became a common destination for many migrants seeking new opportunities and friendlier growing conditions. ${ }^{23}$ In addition, for some rural youth, moving from an agricultural economy to a growing western city could include accessing higher education and along with it the new forms of identity and political organizing beginning to emerge on campuses. ${ }^{24}$

More than a million Oklahomans, Arkansans, Texans, and Missourians made the trek to California. Meanwhile, antimigrant political sentiment strengthened to the point that Los Angeles police chief James E. Davis sent 125 city police officers to patrol the state's major border crossings in 1936, including the border between Oregon and California, eight hundred miles north of Los Angeles. ${ }^{25}$ The following year, California passed an amendment to the state's 1933 Indigent Act, making it a misdemeanor for any person or corporation to knowingly bring an indigent nonresident person into the state, punishable with six months' imprisonment. The law was not actually enforced prior to 1939, when, in response to growing antimigrant hysteria, two dozen individual Southwesterners who helped their friends and relatives enter the state were prosecuted and convicted. ${ }^{26}$ The premise of excluding specifically indigent people was to prevent new arrivals to the state from accessing state benefits for the poor. Rather than impose a durational residency requirement on welfare benefits (as they did later), the California law attempted to entirely exclude anyone who would be likely to receive such benefits.

The constitutionality of the Indigent Act was challenged in Edwards v. California. Fred Edwards was arrested after picking up his indigent brother-in-law, Frank

\footnotetext{
${ }^{22}$ For more on the way early and mid-twentieth century international migration policies changed demographics and generated legal exclusions, see Mae Ngai, Impossible Subjects: Illegal Aliens and the Making of Modern America (Princeton, NJ: Princeton University Press, 2014); Jia Lynn Yang, One Mighty and Irresistible Tide: The Epic Struggle Over American Immigration, 1924-1965 (New York: Norton, 2020); and Roger Daniels, Guarding the Golden Door: American Immigration Policy and Immigrants since 1882 (New York: Hill and Wang, 2005).

${ }^{23}$ For a deeper history of this migration, see Gregory, American Exodus.

${ }^{24}$ Robert Cohen, When the Old Left Was Young: Student Radicals and America's First Mass Student Movement, 1929-1941 (Oxford, UK: Oxford University Press, 1997).

${ }^{25}$ Elisa Minoff, "Free to Move? The Law and Politics of Internal Migration in Twentieth-Century America” (PhD diss., Harvard University, 2013), 130-32.

${ }^{26}$ Edwards v. California, 314 U.S. 160 (1941). For more discussion of this case, see Peter La Chapelle, "At the Crosswords of Whiteness," in Moving Stories: Migration and the American West, 1850-2000, ed. Scott E. Casper and Lucinda M. Long (Reno: University of Nevada Press, 2001).
} 
Duncan, in Texas and bringing him back to California to stay with him and his wife for ten days until Duncan began obtaining aid from the Farm Security Administration. Even as the American Civil Liberties Union (ACLU) legal team had been seeking an appropriate test case for these kinds of antimigrant laws, the ACLU board was split on whether they should take on these antimigrant law cases at all. One letter from a Southern California ACLU attorney-seeking support for the argument that these were important civil liberties cases-described some board members as feeling that a state did have the right to "keep indigents from coming in and becoming a burden upon the taxpayers of our state." ${ }^{27}$ In a particularly painful economic era, even some in the ACLU were sympathetic to the argument of keeping state benefits exclusively for longtime state residents. Eventually, the ACLU argued the case before the Supreme Court in 1941, at which point antimigrant attitudes had dissipated somewhat as the defense industry ramped up in anticipation of entering World War II.

But when the Supreme Court heard the Edwards case, it was also in the early days of the twentieth-century revolution in Fourteenth Amendment constitutional jurisprudence on equal protection. That revolution, in later decades, would recognize unarticulated but fundamental rights, such as the right to decide when and whether to procreate, the right to privacy, the right to vote, and the right to marry, though not the right to education. ${ }^{28}$ The Edwards court unanimously agreed that state laws such as California's were constitutionally invalid, but the justices were deeply split on what legal rationale to apply to such "right-to-travel" cases. Justice James Byrnes authored the unanimous opinion of the court, holding that the California antimigrant law was an invalid use of the state's police powers and violated the Constitution's commerce clause. Byrnes argued this clause had a clear precedent protecting the transportation of persons as interstate "commerce," harkening back to Crandall.

Justice William Douglas, joined by Justices Hugo Black and Frank Murphy, concurred in the case's outcome but wrote separately to argue that the right of people to move freely between states "occupies a more protected position in our constitutional system than does the movement of cattle, fruit, steel and coal across state lines." ${ }^{29}$ Douglas's concurrence suggested that the right to interstate travel was protected as an element of national citizenship under the privileges and immunities clause of the Fourteenth Amendment. Finally, Justice Robert Jackson, concurred but wrote separately to argue with strong sentiment that the right to travel was a key privilege of national citizenship under the privileges and immunities clause, stating that "if national citizenship means less than this, it means nothing." ${ }^{30}$

\footnotetext{
${ }^{27}$ A. L. Wirin to Roger Baldwin, Dec. 27, 1939, microfilm, roll 187, vol. 2222, ACLU Microfilm 1940, American Civil Liberties Union Archives, Princeton University. Also cited in Minoff, "Free to Move?," 209.

${ }^{28}$ For examples of key cases in which the Supreme Court identified (typically for the first time) a fundamental right rooted in a modern Fourteenth Amendment jurisprudence, see Skinner v. Oklahoma, 316 U.S. 535 (1942); Griswold v. Connecticut, 381 U.S. 479 (1965); Eisenstadt v. Baird, 405 U.S. 438 (1972); Roe v. Wade, 410 U.S. 113 (1973); Harper v. Virginia Board of Elections, 383 U.S. 663 (1966); Boddie v. Connecticut, 401 U.S. 371 (1971); and Obergefell v. Hodges, 576 U.S. 644 (2015). However, see also San Antonio Independent School District v. Rodriguez, 411 U.S. 1 (1973), in which the court refused to recognize a right to education as "fundamental" in the Constitution.

${ }^{29}$ Edwards, 314 U.S., at 169.

${ }^{30}$ Edwards, 314 U.S., at 183.
} 
The multiple grounds of analysis in Edwards meant that future court decisions on the right to travel would have to judge which argumentative claim was most persuasive. Most often those cases struck down durational residency claims for welfare benefits, health care, and voting on the grounds that they constituted a denial of equal protection for a "necessity of life." But before those cases, the early 1960s civil rights movement generated new questions for the court about the right to interstate travel. In a broad case stemming from the shooting death of Lemuel Penn, an African American reserve officer, six White Klansmen were indicted for criminal conspiracy, including conspiring to deprive fellow citizens of their civil rights. In United States v. Guest in 1966, the Supreme Court held that violations of the Fourteenth Amendment could be grounds for criminal charges under federal conspiracy laws, including violations of the right to interstate travel. The defendants were charged with conspiring to deprive African American citizens of "the right to travel freely to and from the State of Georgia and to use highway facilities and other instrumentalities of interstate commerce within the State of Georgia." ${ }^{31}$ Though the district court had dismissed that charge, the Supreme Court overturned their ruling and cited Crandall v. Nevada to affirm that the constitutional right of interstate travel "occupies a position fundamental to the concept of our Federal Union."32

Thirteen years after Edwards, the Warren court came to the brink of expanding the unwritten fundamental rights rationale of Edwards into the realm of education in the Brown v. Board of Education decision. This ruling built on a strategic foundation of many cases over the previous years that had chipped away at segregation in public higher education institutions. ${ }^{33}$ Calling education "perhaps the most important function of state and local governments" the court's brief and unanimous ruling led many legal scholars and advocates to assume that education had been named a fundamental right, a hope that increased as unanimous opinions on education desegregation continued for nearly two decades. ${ }^{34}$ This hope would be dashed in the 1973 San Antonio Independent School District v. Rodriguez case, in which the court ruled 5-4 that education was not in the pantheon of "fundamental" rights. ${ }^{35}$ But in the 1960s, the Warren court was still expanding many areas of fundamental rights and civil rights to include marriage, procreation, privacy, and voting. However, the seemingly unanimous and clear right to interstate travel, just like the right to education, did not have an explicit and uniform rationale for its protection and could be located in many different constitutional provisions. Even as advocates in various states were developing arguments to push back against onerous state residency requirements for various benefits, this confused and complicated legal rationale would have implications for how

\footnotetext{
${ }^{31}$ United States v. Guest, 383 U.S. 745 (1966) at 757.

${ }^{32}$ Guest, 383 U.S. 745 (1966), at 757.

${ }^{33}$ See Sipuel v. Board of Regents, 332 U.S. 631 (1948); Sweatt v. Painter, 339 U.S. 629 (1950); and McLaurin v. Oklahoma State Regents, 339 U.S. 637 (1950). For more on this litigation strategy, see Mark V. Tushnet, The NAACP's Legal Strategy Against Segregated Education, 1925-1950 (Chapel Hill: University of North Carolina Press (2005).

${ }^{34}$ Brown v. Board of Education, 347 U.S. 483 (1954), at 9. For other cases, see, e.g., Green v. County School Board of New Kent County, 391 U.S. 430 (1968); Alexander v. Holmes County Board of Education, 396 U.S. 19 (1969); and Swann v. Charlotte-Mecklenburg Board of Education, 402 U.S. 1 (1971).

${ }^{35}$ Rodriguez, 411 U.S. 1 (1973) at 30-31.
} 
far the court would go to protect the right of mobility, particularly in the realm of higher education.

\section{"Necessities of Life" from the 1960s to 1990s: Welfare without Education}

People, particularly low-income people, moving to new states and attempting to access various state benefits after Edwards established the right to move generally, brought with them new cases. These cases helped highlight the Supreme Court's reasoning method in right-to-travel cases, especially the language around "necessities of life" for long durational residency requirements. This rationale, along with a deference to state fiscal decisions, led to the court's tacit approval of many types of state tuition residency differentials in $1973 .{ }^{36}$ But in order to understand why education was carved out as a unique benefit type in the dicta of Vlandis v. Kline, it is first important to understand the way the rights of the poor to move between states and access benefits defined the right to travel from the beginning. Because rights to welfare or medical care were not constructed as "pay-outs" for "pay-ins" in the same way education benefits were, they were defined as "necessities" in a way that avoided the state resident prioritization that triumphed in education.

Protecting the right to interstate travel consistently proved most critical in the case of the poor and their ability to access benefits, and throughout the 1960s, poverty lawyers brought forward cases around discrimination against low-income citizens based on their length of residence. In 1969, the Supreme Court, in Shapiro v. Thompson, ruled that denying state welfare benefits to residents who had resided in the state for less than a year was unconstitutional discrimination because it violated the fundamental right to interstate travel without serving a compelling state interest. One of the justifications the states who had such durational residency rules offered was that they were "an attempt to distinguish between new and old residents on the basis of the contribution they have made to the community through the payment of taxes." But the majority argued that this justification was an unconstitutional violation of the equal protection clause, stating that this "reasoning would logically permit the State to bar new residents from schools, parks, and libraries or deprive them of policy and fire protection. Indeed it would permit the State to apportion all benefits and services according to the past tax contributions of its citizens." ${ }^{37}$ This rationale, disfavored by the more progressive Warren court majority in Shapiro for welfare or necessities of life, eventually became one of the cornerstone arguments in support of maintaining tuition residency differentials.

The 1969 Supreme Court was perhaps at its high point of progressive and expansive equal protection jurisprudence. Shapiro struck down durational residency requirements for state welfare benefits in several states as violating the equal protection clause in the same year the court finally ordered immediate school desegregation in Alexander v. Holmes County. ${ }^{38}$ Shapiro brought more cohesion to the jurisprudence on the right to travel than Edwards, even as the majority of the court only

\footnotetext{
${ }^{36}$ Vlandis $v$. Kline, 412 U.S. 441 (1973).

${ }^{37}$ Shapiro v. Thompson, 394 U.S. 618 (1969), at 632-33.

${ }^{38}$ Shapiro, 394 U.S.; and Alexander, 396 U.S.
} 
agreed with this standard of review on the limited basis of restrictions pertaining to "necessities of life." Justice William Brennan, writing for the Shapiro majority, claimed that the statutes created "two classes of needy resident families" that were identical but for the distinction of residing more than or less than one year in the jurisdiction. ${ }^{39}$ The opinion further argued that it was only on the basis of that small difference that families were granted or denied the means to subsist and "necessities of life." The states had argued that the requirements were necessary to preserve the fiscal integrity of their welfare programs and prevent additional burdens of new indigent recipients; that they rationally sought to discourage indigent people from entering a state solely to obtain higher benefits; and that the distinction between new and old residents was justified on the basis of the level of tax contributions they had made to the community-arguments very similar to those states had made regarding tuition residency discrepancies. Shapiro was a watershed case for the right to travel, but because the language narrowly focused on "necessities of life," it proved to be a mixed precedent for future interstate migration cases, particularly tuition benefits cases.

Shapiro pushed back on discrimination against new state residents by creating a necessities test to determine when such discrimination ran afoul of the Constitution. This milestone was significant in part because it established that exclusion from state benefits could perhaps be justified in the future for "nonnecessities." Meanwhile, a new case on the horizon, Dunn v. Blumstein, focused attention on what exactly qualified as a "necessity." In June 1972, James Blumstein moved to Tennessee to begin a job as an assistant law professor at Vanderbilt University, and on July 1, he attempted to register to vote so he could vote in the highly contested fall presidential elections that year. After the registrar denied his registration on the basis that he had not lived in the state for one year, he brought suit. Tennessee argued that nonresidents would "invade" the state, "colonizing" the vote and perpetrating voter fraud if a shorter durational residency requirement was permitted. ${ }^{40}$ Justice Thurgood Marshall wrote for a majority in an opinion overturning Tennessee's one-year residency requirement, finding it an unconstitutional burden on the fundamental right to vote and the right to interstate travel. The court found that Tennessee had failed to use the least drastic and least burdensome methods to achieve its goal of encouraging voter participation and deterring voter fraud. ${ }^{41}$

Shortly after Dunn, the court heard Memorial Hospital v. Maricopa County, again taking up the question of what would be considered a necessity for protecting the right of interstate mobility. The Arizona Supreme Court had ruled in favor of that state's law requiring a year's residence in a county before someone could receive nonemergency medical treatment or hospitalization at the county's expense. Justice Marshall again wrote for the court's majority in overturning the lower court ruling, reaffirming that restricting the right to travel through durational residency

\footnotetext{
${ }^{39}$ Shapiro, 394 U.S. 618 (1969) at 627.

${ }^{40}$ Dunn v. Blumstein, 405 U.S. 330 (1972), at 345. For more on how durational residency requirements have particularly impacted voting rights, voters, and candidates differently, see Eugene D. Mazo, "Residency and Democracy: Durational Residency Requirements from the Framers to the Present," Florida State University Law Review 43, no. 2 (2017), https://ir.law.fsu.edu/lr/vol43/iss2/8.

${ }^{41}$ Dunn v. Blumstein, 405 U.S., at 353. See also Oregon v. Mitchell, 400 U.S. 112 (1970).
} 
requirements such as these violated the equal protection clause of the Fourteenth Amendment and denied newcomers to a state the "basic necessities of life" as held in Shapiro. ${ }^{42}$ It's important to note that at this point the definition of "necessities of life" was still open, and the court was still amenable to the Marshall interpretation of a far-reaching right to mobility and interstate migration. Though only five justices joined Marshall's rationale that the durational residency requirement was an "invidious classification" impinging on the right to interstate travel, all but Justice William Rehnquist concurred in the result in Memorial Hospital.

Rehnquist argued that the right to travel, as understood in the 1867 Crandall decision, did not address the right to benefits from every state, but "more modestly held that the State could not use its taxing power to impede travel across its borders. ${ }^{43}$ In this narrower interpretation, states would be well within their rights in creating very different benefits schemes for residents and nonresidents. In fact, refusing to recognize state resident status for tuition, as many schools do, as long as the student moved to the state to attend school, does not come close to Rehnquist's extremely narrow, tax-based interpretation of the right to travel. Rehnquist's lone dissent in Memorial Hospital indicated a growing desire of the court's conservative wing to limit presumptive access to a range of benefits, from voting, health care, and welfare to, particularly, divorce and education.

In the 1975 Sosna v. Iowa case, the overall conservative turn of the court that Rehnquist illustrated did establish a majority to successfully narrow the interpretation of the right to mobility and the necessities of life. This solidified the idea of both divorce and education as "portable" benefits that states could limit to residents. The court's majority upheld Iowa's one-year durational residency requirement for divorce by arguing that divorce was not a "necessity of life" in the same way as food or shelter in Shapiro had been, and that the respondent was not "permanently deprived" of the ability to obtain a divorce in Iowa-she would simply have to wait a year. ${ }^{44}$ This idea that divorce was a "portable" benefit, unlike welfare or health care (which would be "consumed" in the state), became a dividing line between the right to divorce or education on one side and the "necessities of life" rights on the other. In this rationale, a divorce or an education enables the recipient to take the privileges accorded by the initial benefit and enjoy them in future state residences, whereas welfare or health care were "used" in the moment within the state. However, not all the justices accepted the idea of such a bright line between "portability" and "consumability" of benefits.

Justice Marshall wrote one of two dissents, arguing that the key element in Shapiro was the right "to migrate, resettle, find a new job, and start a new life." ${ }^{45}$ He claimed that denying the essential right to divorce to new migrants to the state was a penalty for interstate travel that directly impacted the ability to start a new life. For Marshall, the right to marry that had been recognized in cases like Loving $v$. Virginia was compromised without a parallel fundamental right to exit marriage without unreasonable

\footnotetext{
${ }^{42}$ Memorial Hospital v. Maricopa County, 415 U.S. 250 (1974).

${ }^{43}$ Memorial Hospital, 415 U.S. 250 (1974) at 281.

${ }^{44}$ Sosna v. Iowa, 419 U.S. 393 (1975).

${ }^{45}$ Sosna, 419 U.S. 393 (1975) at 427.
} 
roadblocks. ${ }^{46}$ The year before Sosna, Boddie v. Connecticut had in fact overturned the state requirement for payment of court fees and costs in a case involving welfare recipients who sought access to a marriage dissolution but were unable to meet the state's costs. ${ }^{47}$ Marshall relied on Boddie to emphasize the state's monopoly on the process of exiting a marital relationship and the intrinsically connected ability to start a new life in a new place.

After Sosna, advocates largely stopped bringing the kinds of residency benefits cases that had been prevalent in the early 1970s around welfare, voting, medical care, and divorce (including the lone tuition residency case, Vlandis v. Kline, from 1973). The Supreme Court's shift away from more expansive equal protection jurisprudence was already underway and it had indicated the limits of the right to travel and access state benefits in Sosna.

But the idea of rewarding state residency with specific state benefits would return once more in a case from Alaska, Zobel $v$. Williams in 1982, that especially highlighted the historical absurdity of claiming entitlements based on residency length and accidents of timing. In many ways, the Zobel case, while uniquely tied to residency since statehood, also paralleled the argument that many supporters of tuition residency differentials made: that long-term familial settlement within a state entitled the children or descendants of a family unit to specific and targeted benefits as residents.

Alaska's dividend law distributed a portion of the funds from its mineral income to citizens in different amounts depending on their length of residency. ${ }^{48}$ The 1980 law distributed one dividend unit from the Permanent Fund's earnings to each adult resident for each year of residency in the state subsequent to 1959, the first year of statehood. The appellants had resided in Alaska since 1978 and contested this system of distribution as unconstitutional because it drew distinctions among and between the entire class of people who were Alaska residents when the dividend scheme was enacted in 1980. In Zobel, the Supreme Court, with Chief Justice Warren Burger writing the majority opinion, overturned the provision as an unconstitutional violation of the Fourteenth Amendment's equal protection clause because it created fixed, permanent distinctions among a group of bona fide residents at the time of the law's enactment-distinctions that would only multiply the number of classes of people generated by the law. ${ }^{49}$ The exponential expansion of the math worked against the state's attempt to delineate residency benefits and prioritize longer residency duration. However, even Alaska never went as far as to say that if a resident moved to Alaska to take advantage of the dividend, they were excluded (as with many tuition schemes).

The case that finally laid out a more comprehensive and (somewhat) unified judicial framework of analysis for right-to-travel cases came in 1999 in Saenz v. Roe. A 1992 California statute provided that new residents who had lived in the state less than twelve months were only eligible to receive welfare benefits in the amount their previous state of residence would have paid (California's welfare benefits

\footnotetext{
${ }^{46}$ Sosna, 419 U.S. 393 (1975) at 420.

${ }^{47}$ Boddie, 401 U.S., at 371 . The court concluded that because marriage was a centrally important relationship in society, and because the state held a monopoly on the means to dissolve it, denying someone that opportunity solely because of inability to pay violated due process.

${ }^{48}$ Zobel v. Williams, 457 U.S. 55 (1982).

${ }^{49}$ Zobel, 457 U.S.
} 
tended to be, on average, more generous than many states). ${ }^{50}$ The same year, three recent California residents challenged the law after moving to California (or returning to California) to live with relatives in order to escape an abusive family situation. ${ }^{51}$ The Supreme Court relied on the privileges and immunities clause-a rarely invoked constitutional provision - to hold that a statutory limitation on state welfare benefits for resident citizens who had recently arrived in the state violated the constitutional right of interstate travel. Justice John Paul Stevens, writing for the majority, explained:

The "right to travel" discussed in our cases embraces at least three different components. It protects the right of a citizen of one State to enter and to leave another State, the right to be treated as a welcome visitor rather than an unfriendly alien when temporarily present in the second State, and, for those travelers who elect to become permanent residents, the right to be treated like other citizens of that State. ${ }^{52}$

However, importantly, this right was focused on "nonportable" benefits, such as welfare (unlike tuition or divorce) for intended domiciliaries. This brings us squarely to the issue of state residency for tuition and the question of "domicile." As a more restrictive legal category than residency, domicile is closest to how many courts have treated the supposedly portable benefit of education. Domicile is more restrictive because it incorporates intentionality, a commitment to settle and reside in a place long term. As neither a "necessity of life" for right-to-travel jurisprudence nor a "fundamental right" for Fourteenth Amendment jurisprudence, education was positioned to be the exception to the logic of access and "the right to be treated like other citizens of that State" delineated in Saenz. ${ }^{53}$

The language of deservingness has been applied to welfare benefits in various ways in US history, from explicitly racial to deeply gendered articulations (often both), and from deservingness based on grief and loss to deservingness based on the innocence and dependence of children. It has been a regulatory tool, a surveillance system, and a perennially contentious political football. ${ }^{54}$ Yet welfare in the Shapiro case also

\footnotetext{
${ }^{50}$ See Cal. Welf. \& Inst. Code Ann. $\$ 11450.03$. You may well exclaim, “But Shapiro!" In the wake of Shapiro a number of states, including California, enacted durational residency requirements for welfare that didn't directly deny payments but limited payments for the first year of their residency in the new state to the level they would have received in their prior state of residence. As Justice John Paul Stevens's majority opinion noted, the cash benefit at the time of the decision for a family of two-a mother and one child-was \$456 a month in California, but in neighboring Arizona it was only \$275 a month.

${ }^{51}$ Saenz v. Roe, 526 U.S. 489 (1999).

${ }^{52}$ Saenz, 526 U.S., at 500.

${ }^{53}$ For a discussion of portable benefits and an argument that the portability distinction in Saenz is vague and should not be used to prevent courts from using the Saenz precedent to reexamine and overturn durational residency tuition laws, see Douglas R. Chartier, "The Toll for Traveling Students: Durational-Residence Requirements for In-State Tuition After Saenz v. Roe," Michigan Law Review 104, no. 3 (2005), https://repository.law.umich.edu/mlr/vol104/iss3/5. For more on domicile, see Llewellyn, "Citizens Without Statehood"; and Kerry Abrams and Kathryn Barber, "Domicile Dismantled," Indiana Law Journal 92, no. 2 (Spring 2017), https://www.repository.law.indiana.edu/ilj/ vol92/iss2/1.

${ }^{54}$ For more analysis of the racialized and gendered implications of debates on welfare, see Premilla Nadasen, Welfare Warriors: The Welfare Rights Movement in the United States (New York: Routledge, 2004); Jennifer Mittelstadt, From Welfare to Workfare: The Unintended Consequences of Liberal Reform,
} 
became the paradigmatic judicial example of a benefit that would be unjust to exclude new state residents from receiving solely because of their newness, given its necessity. The logic of deservingness for welfare has often relied more on status and public sympathy (widows, mothers, children) than on a construction of prior taxpayer contributions as a reciprocal exchange for the benefit later received. This reliance on generalized sympathy in welfare policy has created many opportunities for both blatant and subtle discrimination, and the absence of taxpayer reciprocity claims also constantly reinforces the precarity of welfare benefits. But the legal and policy logic of deservingness for education solidified around a different framework. For education, an assumption of parental taxpayer contributions and the deservingness of a college-age child relying on their parents' state of residence defined both the problem and the solution. The distinction of past parental contributions and the assumption of adult children as quasidependents and perennially temporary residents has helped carve out an exception for higher education from the other benefits accorded to new state residents.

\section{Domicile, Residency, and Tuition in State Courts: 1920s-1960s}

Like many states in the early twentieth century, California had a tradition of free public higher education from its founding. And like the general ethos of generous benefits in California tested in the Saenz case, California's free public higher education was not unique among states but became more significant as the state's population and higher education system grew rapidly. ${ }^{55}$ While the university's 1868 charter affirmed free tuition for "residents" of the state, there is no evidence of out-of-state nonresident fees until 1920. It is perhaps not a surprise that California began imposing these fees at that point, since the number of students in the University of California (UC) system grew from 1,783 in 1900 to 10,599 in 1920-more than fivefold in a single generation. ${ }^{56}$ In 1921, according to the UC Berkeley student newspaper, nonresidents could attend UC campuses for $\$ 75$ per year while residents were required to pay an "incidental fee" of $\$ 25$ a year but were not charged tuition. The 1922 Bryan v. Regents of the University of California case immediately challenged the imposition of a nonresident fee for higher education. The California Supreme Court affirmed that a regulation requiring that a student maintain a residence in the state of California for one taxation period (that is, one year) prior to entering the university as evidence of her "intention to remain a permanent resident of the state" was not unreasonable or arbitrary and did not violate the privileges and immunities clause of the California constitution. ${ }^{57}$

1945-1965 (Chapel Hill: University of North Carolina Press, 2005); and Marisa Chappell, The War on Welfare: Family, Poverty, and Politics in Modern America (Philadelphia: University of Pennsylvania Press, 2012).

${ }^{55}$ For a detailed history of how California's network of public colleges and universities became an influential model, see John Aubrey Douglass, The California Idea and American Higher Education (Palo Alto, CA: Stanford University Press, 2000). For a broader discussion of the social contract at the heart of public university admissions and access, using the UC system as a case study, see John Aubrey Douglass, The Conditions for Admission: Access, Equity and the Social Contract of Public Universities (Palo Alto, CA: Stanford University Press, 2007).

${ }^{56}$ Bryan v. Regents of University of California, 188 Cal. 559 (S. Ct. of Cal. 1922) at 561.

${ }^{57}$ Bryan v. Regents, 188 Cal., at 561-562. 
In upholding this one-year requirement, however, the court explicitly connected it to the (at the time) identical one-year residence requirement before obtaining the right to vote, later overturned in Dunn v. Blumstein in 1972. Finally, the court expressed concern that the state's expenditures for the public university system were a "heavy burden upon the taxpayers of the state" and that since taxes (at the time) were payable annually, the requirement that students reside in the state for one taxable year did not violate their constitutional rights.

Not all states followed California's lead, however, even as states over the next several decades moved at various paces to impose tuition for the first time on both nonresidents and, eventually, on residents. Some, like Idaho, found presumptions of nonresidency unreasonable. As late as 1960, the Idaho Supreme Court overturned an Idaho regulation requiring students to retain their initial nonresident status if they had not lived in the state for more than six months prior to their university admission. ${ }^{58}$ The student in that case was a twenty-five-year-old military veteran who began taking classes at Idaho State College in 1957, after his military service; he paid nonresident tuition the first year but protested when it was required the second year after that. The Idaho court found that the regulation essentially meant a student who began as a nonresident would remain as such throughout his collegiate career and that the regulation was "arbitrary, capricious and unreasonable."

Other states, such as Colorado and Iowa, carried forward the logic of the earlier Bryan case from California by indicating that tax-supported institutions could reasonably impose added requirements on nonresidents based on the entitlement of residents. In a 1964 Colorado case, the plaintiff student argued he was a resident and a domiciliary of Colorado from 1960 through 1964 and had paid out-of-state tuition during his entire time there nonetheless. He contended that the whole classification of in-state and out-of-state residency for tuition violated the equal protection, due process, privileges and immunities, and commerce clauses of the US Constitution and the due process clause of the Colorado constitution. ${ }^{60}$ The state court upheld the classification scheme as a reasonable legislative determination for "admission to the tax supported University of Colorado" and stated that the only requirement was "equality and uniformity between the persons in separate classes."

Like Colorado, the principle in a key case in Iowa revolved around state taxpayer support of the public university and the related entitlement to lower-cost educational access as a result. In this case, a nonresident male student, George Clarke, had married Joan Weaver, a lifelong resident of Iowa, and he was planning to attend law school at the State University of Iowa (SUI). After paying the nonresident fee during his undergraduate years at SUI, he contested his nonresident classification for the purpose of attending law school. The court argued that his case should be viewed through the lens of a "rational basis" review, saying that the classification was not arbitrary if it was rationally related to a legitimate state object or purpose. The court explained that the "students at SUI who are classified as nonresidents are

\footnotetext{
${ }^{58}$ Newman v. Graham, 82 Idaho 90, 349 P.2d 716 (1960), at 95.

${ }^{59}$ Newman, 82 Idaho, at 95.

${ }^{60}$ Landwehr v. Regents of the University of Colorado, 396 P.2d 451 (1964).

${ }^{61}$ Landwehr, 396 P.2d, at 453.
} 
charged a higher tuition than resident students," which the state justifies "primarily on the basis that resident students or their parents pay taxes to the State of Iowa which, in turn, supports and maintains SUI." ${ }^{12}$ However, the judges did remand the case back to the review committee on residency status to reconsider the plaintiffs classification in light of what the court described as the application of the correct standards in an "unduly rigid" way. ${ }^{63}$

By the time the Idaho, Colorado, and Iowa cases were settled, California began to revisit tuition and residency requirements in the 1969 case of Kirk v. Board of Regents. In some sense, this case brought by Deborah Kirk was the opposite of the Clarke case. She based her argument on the California Government Code, which stated that "the residence of the husband is the residence of the wife." ${ }^{364}$ Kirk thus argued that her residence was "derivative," like that of a minor, and therefore she should retroactively be classified as a state resident for the year prior to her admission to the university (though they had married the July immediately before she planned to start classes at UC). Kirk was decided the same year as Shapiro, and Kirk relied on Shapiro to argue that California's durational residency classification system violated her fundamental right to interstate travel. But the state court disagreed, ruling that Shapiro was decided only in relation to benefits for basic human necessities and that therefore the scheme for tuition residency need only be examined under rational basis review. ${ }^{65}$ Under that review standard, they argued that there was a reasonable relationship of the regulation to a legitimate objective of the state of California. Once again, the winning argument for the court was based on the idea of fiscal integrity. The majority argued that cost-spreading through differential tuition was reasonable under the assumption that resident students or their parents paid more taxes to the state, which helped maintain the university.

\section{Vlandis v. Kline: "State Colleges Spared"}

While these state-level decisions often linked gender, marriage, family structure, taxation, mobility, and residency status, none of them had reached the US Supreme Court. That changed in the case of Vlandis v. Kline. Decided by the Supreme Court in 1973, this case followed the line of previous cases that had built up a presumption that many state benefits, such as welfare and voting, should be more available to newcomers and that struck down lengthy durational residency requirements. ${ }^{66}$ In fact, Vlandis was brought after Shapiro and Dunn but before Memorial Hospital and Sosna, in a moment that illustrated the turn of the court in the mid-1970s toward constricting equal protection jurisprudence overall. ${ }^{67}$

\footnotetext{
${ }^{62}$ Clarke v. Redeker, 259 F. Supp. 117 (1966), at 123.

${ }^{63}$ Clarke, 259 F. Supp. 117, at 125. For a discussion of derivative domicile and the Clarke case, arguing that tuition litigation highlights how changing ideas of gender equality and age of adulthood starting in the 1970s "have rendered domicile a clumsy and often useless tool," see Abrams and Barber, "Domicile Dismantled," 387, 430.

${ }^{64}$ Kirk v. Board of Regents of the University of California, 273 Cal.App.2d 430 (1969), at 434.

${ }^{65}$ Kirk, 273 Cal.App.2d at 441.

${ }^{66}$ Vlandis, 412 U.S. 441 (1973).

${ }^{67}$ See Rodriguez, 411 U.S as an example of the closing of the judicial door on expanding $14^{\text {th }}$ Amendment scrutiny.
} 
Once more, the Vlandis case had some early roots in California. It began when Margaret Marsh attended school in California as a resident in 1970. She was engaged to Peter Kline, a Connecticut resident, and believed that after their marriage she would be classified as a Connecticut resident and entitled to the standard resident tuition rate. Thus, she moved across the country to live permanently in Connecticut with her new husband. Although she registered to vote in Connecticut, she was irreversibly classified by the University of Connecticut as an out-of-state student. Connecticut's policy was not unique, but it was a stringent irrebuttable presumption that if a student was outside the state at the time they applied for admission, or anytime in the year prior, they remained a nonresident their entire time as a student in Connecticut without the opportunity to contest that classification. ${ }^{68}$ Once so classified, there was no opportunity to reconsider that determination or for those classified to present evidence of their genuine residence in the state in order to alter the classification.

Marsh combined her case with a similar Connecticut case for appeal to the Supreme Court in Vlandis. Patricia Catapano had applied for admission to the University of Connecticut while living in Ohio. She was not married to a resident, but she moved to Connecticut, registered her car, registered to vote, and obtained a Connecticut driver's license. She was also classified as an out-of-state student by the university. The two women brought suit, alleging that their classification as permanent nonresidents for tuition purposes infringed on their due process rights and violated the Fourteenth Amendment's equal protection clause. ${ }^{69}$

The majority opinion in Vlandis stated that irrebuttable presumptions were "disfavored" by the due process clause. Connecticut's system was overturned despite the state defending its statutory scheme on the basis of cost equalization; reasonably favoring "established residents whose past tax contributions to the State have been higher"; and administrative certainty. ${ }^{70}$ However, the majority also repeatedly affirmed that states may impose separate durational residency requirements for out-of-state tuition as long as they are not permanently irrebuttable, as they were in this case.

Justice Marshall concurred with the outcome in Vlandis, but he and Justice Brennan argued that important equal protection questions should be examined and that one-year residency rules should not have been casually affirmed in the majority ruling. But Chief Justice Burger argued in dissent that "it is not narrow provincialism for the State to think that each State should carry its own educational burdens." ${ }^{71}$ Though it may be technically dictum (nonbinding as precedent), the language in Justice Potter Stewart's majority opinion asserting that states "can establish such reasonable criteria for in-state status as to make virtually certain that students who are not, in fact, bona fide residents of the State, but who have come there solely for educational purposes, cannot take advantage of the in-state rates" has been consistently invoked as settling the question of resident tuition law. ${ }^{72}$ Thus, despite the

\footnotetext{
${ }^{68}$ Conn. Gen. Stat. Rev. $\$ 10-329$ (b) (Supp. 1969) as amended.

${ }^{69}$ Vlandis, 412 U.S., at 444.

${ }^{70}$ Vlandis, 412 U.S., at 449.

${ }^{71}$ Vlandis, 412 U.S., at 460.

${ }^{72}$ Vlandis, 412 U.S., at 453-54.
} 
fact that the ruling in the actual case struck down the residency requirement at issue, Vlandis is seen, like Sosna, as a case that shut the door on broader understandings of the right to travel and specifically the right to receive equal access to public educational institutions.

Both before and after Vlandis, students with complex and difficult circumstances attempted to plead their case for special residency exceptions in California and other states, virtually always being turned down. While Vlandis established that there was a minimal right to "rebut" residency determinations in theory, in practice institutions had extensive leeway on what they considered sufficient evidence of residency. In one instance, Will Geselbracht wrote in on his son Lance's behalf after his son's scholarship to UC Davis was withdrawn due to his "nonresidency" in 1973. Will had lived and worked in California for nearly forty years and his son had lived his entire life of "18 plus years" in California and had just graduated from high school in Sacramento. But Will had lost his job due to budget cuts in 1971 and was unable to find work in California, forcing him to move to Portland for work to support his two older children in California universities. Will argued vehemently that the intent of the code-in his estimation "to insure that California residents who have been paying the taxes that support the university, receive preferential treatment"-demanded that his son be granted residency status. He pointed to several decades of his paying both state income taxes and property taxes and his son's lifelong residence there. His request was ultimately denied, like virtually every other appeal to the residence attorneys in the UC system during the 1960s and 1970s. ${ }^{73}$ Given the strictures of the domicile standard, it is possible to be a domiciliary of no state "for tuition purposes," even as a citizen and resident, as some of Vlandis's critics have noted. ${ }^{74}$

The New York Times mentioned the Vlandis case only briefly, months after the decision came down, in an article focused on the fiscal near-miss the institutions had experienced. ${ }^{75}$ The article discussed the anxiety of colleges and universities after the Twenty-Sixth Amendment had lowered the voting age to 18 in 1971, suggesting that students' residence need not be expected to relate to their parents' residence after the age of majority. Yet, as the article pointed out, given the exception carved out in Vlandis, educational institutions could continue to charge differential tuition as long as they provided some rebuttable opportunity for students to challenge residency determinations. Drawing on Michigan as an example, the Times looked at what 22 percent of the 35,149 students at the University of Michigan would have to do to prove residency after the (recently increased) waiting period of a year. The requirements included: in-state sources of financial support, owning a home in the state, and accepting an offer of permanent Michigan employment. The distinction between "portable" and "nonportable" benefits had pushed education benefits into a restrictive residency determination that looked far more like domicile than virtually any other benefit.

\footnotetext{
${ }^{73}$ Will Geselbracht to Charles Hitch, June 7, 1973; and John F. Lundberg to Will Geselbracht, Aug. 7, 1973, folder 13, box 30, President's Records.

${ }^{74}$ Llewellyn, "Citizens Without Statehood," 794.

${ }^{75}$ Evan Jenkins, "State Colleges Spared from Expected Losses in Out-of-State Tuition Fees," New York Times, Dec. 2, 1973, 30.
} 


\section{Undocumented Students and Residency Bars on Educational Access}

But education residency cases were also by no means limited to postsecondary students attending state colleges and universities. Another group of cases pointed toward a question around state differences in granting in-state resident tuition to undocumented students. In Texas, in particular, both immigration status and residency status (as a possible proxy for race or family background) for primary and secondary school children were central political issues in the early 1980s. First, Texas passed a statute forbidding local school districts from providing public education to the children of undocumented immigrants by denying state funds to educate children not "legally admitted" into the United States and authorizing school districts to deny enrollment to those children. In 1982, in Plyler v. Doe, the Supreme Court ruled that the Texas law went too far in potentially creating a "permanent caste" of people within the state who had been denied the basic opportunity for primary and secondary education. ${ }^{76}$

The year after Plyler, in Martinez v. Bynum, the Supreme Court again addressed attempts to exclude certain children from educational benefits in Texas. This case turned directly on immigration status or parents' residency or status. In Martinez, a young student named Roberto Morales, a US citizen who had been born in McAllen, Texas, but who had lived with his parents in Mexico until he was eight years old, was excluded from the public school in McAllen. The school district's rationale was that Morales had returned to live with his married sister in Texas because he wanted to learn English and intended to remain in McAllen to complete his schooling. That intention (and the fact that his sister was not his guardian, merely his custodian) allowed the school district to disqualify him from the public education system. Texas Education Code 21.031(d) permitted a school district to deny tuitionfree admission to its public schools for a minor living apart from a parent or guardian if their presence was "for the primary purpose of attending the public free schools." ${ }^{.77}$ This language was very similar to the language of many higher education institutions and states.

The court upheld this residency requirement, with only Justice Marshall dissenting. The majority, in an opinion written by Justice Lewis Powell, argued that the residency requirement for free public schools did not burden the constitutional right to interstate travel "for any person is free to move to a State and to establish residence there." ${ }^{78}$ In his dissent, Justice Marshall pointed out that it was a misinterpretation of traditional definitions of "residency" to suggest that intent to remain "indefinitely" was a standard element. In fact, he argued, this was the traditional definition of domicile rather than residence and created an extraordinarily high bar for claiming residency status. Marshall argued that there was no precedent in the Supreme Court's prior reasoning to suggest that a state could close its schools to all but domiciliaries. ${ }^{79}$ Yet by the 1980 s, Marshall's view questioning the overly burdensome

\footnotetext{
${ }^{76}$ Plyler v. Doe, 457 U.S. 202 (1982). For more on this case, see Michael A. Olivas, No Undocumented Child Left Behind: Plyler v. Doe and the Education of Undocumented Schoolchildren (New York: New York University Press, 2012).

${ }^{77}$ Texas Educ. Cod Ann. $\$ \$ 21.031$ (d). Martinez v. Bynum, 461 U.S. 321 (1983), at 323.

${ }^{78}$ Martinez 461 U.S. 321 (1983), at 328-329.

${ }^{79}$ Martinez v. Bynum, 461 U.S., at 337-338.
} 
logic of domicile underpinning educational residency laws had entirely lost favor with the Supreme Court's growing conservative majority.

A final piece of the state story returns us to California in a 2010 class action case decided by the California Supreme Court. ${ }^{80}$ In Martinez v. Regents of University of California, a class of US citizen nonresident students contested their denial of exemption from nonresident tuition. They demanded that the relevant portion of the California Education Code be invalidated under the logic of federal preemption. The California law provided that an undocumented student who had attended high school in California for three or more years and graduated from a California high school could be exempt from paying nonresident tuition. The federal statute under consideration was enacted in 1996 as part of the omnibus Illegal Immigration Reform and Immigrant Responsibility Act. ${ }^{81}$ This act provided, in complicated terms, that an undocumented state resident could not receive a benefit from a state-such as in-state tuition-unless any US citizen who was not a state resident could also receive that benefit. On appeal, the California Supreme Court found that the exemption from paying nonresident tuition was based on grounds-such as high school attendance and graduation- "other than residence." This meant that the federal law banning states from exempting undocumented students "on the basis of residence" did not preempt the state law. ${ }^{82}$ The anti-immigrant sentiment behind the act was also attempting to create a catch-22 for states that wished to recognize the actual residence of their undocumented residents. If they eliminated the out-of-state tuition distinction entirely, they would not be violating the law, but the state institutions would lose significant funding they relied on from out-of-state students. The Supreme Court denied certiorari in Martinez, but it is still possible that a state case on undocumented tuition equity laws will reach the court in the coming years. $^{83}$

\section{Conclusion}

The residency cases outlined in this study have left a legacy that continues to shape contemporary higher education policy. Assumptions about local and state financing have been deeply entrenched in public higher education systems as symbols and sources of pride for state identity, yet federal funding began to overtake state funding

\footnotetext{
${ }^{80}$ Martinez v. Regents of University of California, 50 Cal. 4th 1277 (S. Ct. Cal. 2010).

${ }^{81}$ Illegal Immigration Reform and Immigrant Responsibility Act of 1996, Pub. L. No. 104-208, 110 Stat. 300-672, Sec. 505. For background leading up to this law, see Michael Olivas, "Storytelling Out of School: Undocumented College Residency, Race, and Reaction," Hastings Constitutional Law Quarterly 22, no. 4 (1995), 1019-86.

${ }^{82}$ Martinez v. Regents of University of California, 50 Cal. 4th 1277 (S. Ct. Cal. 2010) at 1286-87.

${ }^{83}$ For further discussion of undocumented college student residency and tuition litigation, see Thomas R. Ruge and Angela D. Iza, "Higher Education for Undocumented Students: The Case for Open Admission and In-State Tuition Rates for Students without Lawful Immigration Status," Indiana International and Comparative Law Review 15, no. 2, (2005), 257-78; Michael Olivas, "IIRIRA, the Dream Act, and Undocumented College Student Residency," Journal of College and University Law 30, no. 2 (2004), 435-64; and Laura Hernandez, "Dreams Deferred-Why In-State College Tuition Rates Are Not a Benefit under the IIRIRA and How This Interpretation Violates the Spirit of Plyler," Cornell Journal of Law and Public Policy 21, no. 3 (Spring 2012), https://scholarship.law.cornell.edu/cjlpp/vol21/iss3/2.
} 
at precisely the same moment large numbers of students from underrepresented backgrounds were entering en masse. ${ }^{84}$ As a 2018 Atlantic article suggested, based on previously unpublished data from the State Higher Education Executive Officers Association, states with high levels of racial diversity and Republican-controlled governments are primarily the ones that have most rapidly shifted responsibility from tax funding to tuition since the 2008 recession. According to Michael Sorrell, president of Paul Quinn College, a historically black college in Dallas, in an allusion to the nearly simultaneous entrance of diverse and historically underrepresented students in public higher education and the exit of state government funding: "There's an argument to be made that part of the reason we see a reduction in support is because the legislators are looking at the students and not seeing themselves." ${ }^{35}$

Higher education systems have attempted to compensate for the retreat in state funding in various ways. And as high nonresident tuition rates deter qualified low-income, out-of-state students from applying to state institutions, studies have shown a decline in admissions of students of color to certain prestigious in-state schools in recent years compared to wealthy, often White, out-of-state students. ${ }^{86}$ Disadvantaged students are doubly disadvantaged in that they cannot simply apply to a different state's higher education system without themselves taking on enormous amounts of debt to pay out-of-state tuition.

For other state benefits, though states have varying requirements today, none has as long a durational residency requirement as tuition for higher education, despite the courts' relatively consistent skepticism toward lengthy residency requirements that appear to create inequalities between new and old state residents. ${ }^{87}$ For voting, state residency requirements vary from ten to thirty days (though some states have various mechanisms to exclude students). ${ }^{88}$ Divorce has been treated as a more "portable" benefit, akin to education, and states vary widely, from no waiting period to thirty to ninety days (the most common) to longer. Yet even for divorce, authorities never examine the individual's motive or intent for seeking residency, and few states today have the one-year maximum requirement contested in Sosna. ${ }^{89}$

Historically, states provided significantly more funding than the federal government up until 2012, when state spending declined in the wake of the Great Recession and

\footnotetext{
${ }^{84}$ See Newfield, Unmaking the Public University at 53-67 for a discussion of the conservative backlash to "PC" culture on campuses as student populations became more diverse and more representative.

${ }^{85}$ Ronald Brownstein, "American Higher Education Hits a Dangerous Milestone," The Atlantic, May 3, 2018, https:/www.theatlantic.com/politics/archive/2018/05/american-higher-education-hits-a-dangerous-milestone/559457/.

${ }^{86}$ Jeremy Ashkenas, Haeyoun Park, and Adam Pearce, "Even With Affirmative Action, Blacks and Hispanics Are More Underrepresented at Top Colleges Than 35 Years Ago," New York Times, Aug. 24, 2017, https://www.nytimes.com/interactive/2017/08/24/us/affirmative-action.html; and Sara Garcia, "Gaps in College Spending Shortchange Students of Color," Center for American Progress, April 5, 2018, https://www.americanprogress.org/issues/education-postsecondary/reports/2018/04/05/448761/gaps-collegespending-shortchange-students-color/.

${ }^{87}$ Anderson, "Strangers in Their Own Land," 1058.

${ }^{88}$ National Conference of State Legislatures, "Voter Registration Is All about Residency (and Domicile)," The Canvass, Issue 69, May 2016, http://www.ncsl.org/Documents/Elections/The_Canvass_May_2016.pdf; and Voting Rights Act of 1965, Pub. L. No. 89-110, 79 Stat. 437, Sec. 202; and Mitchell, 400 U.S., at 118.

${ }^{89}$ Sosna, 419 U.S., at 405.
} 
federal investments in Pell Grants and other funding increased dramatically-making higher education funding from states and the federal government more equal than at any time in recent decades. ${ }^{90}$ Pew Trusts found that federal spending on higher education in 2013 totaled $\$ 75.6$ billion dollars, while state spending totaled $\$ 72.7$ billion dollars (excluding federal student loans and higher education tax expenditures). ${ }^{91}$

Higher education-particularly publicly funded higher education since the midnineteenth century-has served as the epitome of economic mobility and the sine qua non of meritocracy in the mythology of the United States. Yet students are often funneled or locked into institutions of varying resource levels, curricular breadth or specialization, and capacities not because of merit, future interests, or capability. Their educational choices are determined in part by a narrow definition of residence-an accident of birth-as well as cost. These foundational exclusions are built into the seemingly neutral historical systems of financial aid, state taxation, and public funding. The purported distinction between welfare's consumability and education's portability "spared" public institutions from the fiscal impacts of lost nonresident tuition dollars after the Twenty-Sixth Amendment. And repeatedly, the argument that state residents and their adult children deserved priority through a sort of legacy taxpayer reciprocity structure has swayed courts and legislatures to maintain these systems of differential tuition.

Space matters, particularly in a public education system that treats out-of-state and in-state students differently, and the state residence requirement has taken hold of the finance structure of public colleges and universities, with ongoing ramifications. Public higher education has expanded and grown rapidly in the twentieth century in part through reliance on disproportionately high out-of-state student tuition rates. As politicians debate federal funding to make public higher education more accessible for all, it is important to consider whether that form of reliance should remain intact. ${ }^{92}$ And ultimately, whether the judicially exceptional status of education as a portable benefit should outweigh the right of an individual to leave their place of birth and carve out their own life without incurring extra burdens.

Camille Walsh, JD, PhD, is an Associate Professor of American and Ethnic Studies and Law, Economics and Public Policy at the University of Washington Bothell. Her book, Racial Taxation: Schools, Segregation, and Taxpayer Citizenship, 1869-1973, was published in 2018. She thanks the HEQ editors and anonymous reviewers for their helpful comments and suggestions, and UWB for the funding that enabled this research.

\footnotetext{
${ }^{90}$ Pew Trusts, "Federal and State Funding of Higher Education: A Changing Landscape," June 11, 2015, http://www.pewtrusts.org/en/research-and-analysis/issue-briefs/2015/06/federal-and-state-funding-of-highereducation.

${ }^{91}$ Pew Trusts, "Federal and State Funding of Higher Education."

${ }^{92}$ For example, the 2017 College for All proposal introduced by Senator Bernie Sanders maintained the presumption of "in-state" and "out-of-state" students for the purposes of public tuition remission, making eligibility limited to students who were either enrolled in a community college in a state in which they are resident or were "a working class or middle-class student" enrolled in a public institution "in the State in which the individual is a resident." See College for All Act of 2017, S. 806, 115th Cong. $\$ 901$ (2017).
}

Cite this article: Camille Walsh, "The Right to Residency: Mobility, Tuition, and Public Higher Education Access," History of Education Quarterly 61, no. 3 (August 2021), 297-319. https://doi.org/10.1017/ heq.2021.32. 